\title{
Kajian Teknis dan Analisa Finansial Pembesaran Ikan Nila Merah (Oreochromis niloticus) Sistem Kolam Air Deras Menggunakan Pakan yang Berbeda di PT Ikan Bangun Indonesia (IWAKE) Bogor, Jawa Barat
}

\section{Technical Study and Financial Analysis of Red Tilapia Cultivation (Oreochromis niloticus) in Running Water System Using Different Feeds at PT Ikan Bangun Indonesia (IWAKE) Bogor, West Java}

\author{
Raihan Maulana Firdaus*1, Mugi Mulyono², Moch. Farchan ${ }^{2}$ \\ ${ }^{1}$ Program Sarjana Terapan, Politeknik Ahli Usaha Perikanan Jakarta 12520, Indonesia \\ ${ }^{2}$ Teknologi Akuakultur Politeknik Ahli Usaha Perikanan Jakarta 12520, Indonesia \\ *Email : raihanmaulanaf@gmail.com \\ Submited: 14 Juli 2020 \\ Revised: 18 September 2020 \\ Accepted: 22 September 2020
}

\begin{abstract}
Abstrak
Ikan Nila merah (Oreochromis niloticus) merupakan salah satu komoditas yang dapat dibudidayakan pada kolam air deras. Dengan teknologi kolam air deras yang bergantung pada pemberian pakan. Biaya pakan dalam produksi berkisar 60-70\% dari keseluruhan biaya. Oleh karena itu, dibutuhkan inovasi pada pakan untuk menekan biaya produksi. Maka dilakukan percobaan yang bertujuan mengetahui efisiensi dalam pemberian pakan maggot dan pakan pellet pada ikan Nila Merah sistem kolam air deras. Beberapa percobaan dilakukan dengan memberikan full pakan pellet dan subsitusi pada pakan maggot 50\%. Percobaan ini dilakukan terhitung 75 hari dari tanggal 2 Maret 2020 hingga 15 Mei 2020. Parameter yang diamati yaitu Teknik produksi dari penebaran hingga panen, frekuensi dan dosis, rasio konversi pakan, pertambahan berat harian, kelulushidupan, dan parameter kualitas air ( $\mathrm{pH}$, suhu, oksigen terlarut dan debit air). Pengamatan berat rata rata harian dilakukan setiap satu minggu sekali. Dengan pemberian pakan yang berbeda menghasilkan FCR yang lebih tinggi dan pakan pellet lebih unggul dibandingkan pakan maggot. Pakan pellet menghasilkan FCR 2,8 dan pakan kombinasi maggot dan pellet menghasilkan 3,79. Dengan kerugian menggunakan pakan kombinasi maggot dan pellet Rp 15.709.111. Berdasarkan hasil tersebut percobaan pakan maggot yang diberikan tidak memberikan pengaruh yang lebih baik dari pemberian pakan pellet.

Kata Kunci : Percobaan, Ikan Nila Merah, Pemberian Pakan Berbeda, FCR, Analisa Finansial.

Abstract

Red tilapia is one of the commodities that can be cultivated in the running water pond. With the technology of running water ponds that depend on feeding. The cost of feed in production ranges from $60-70 \%$ of the total cost. Therefore, innovation in feed is needed to reduce production costs. Then an experiment was carried out aimed at finding out the efficiency in feeding maggot and pellet feed in red tilapia in the running water pond system. Some experiments were carried out by giving full feed pellets and substitution in maggot feed 50\%. This research was conducted 75 days from March 2, 2020 to May 15, 2020. Observed parameters were production technique from stocking to harvest, frequency and dose, feed conversion ratio, daily weight gain, survival rate, and parameters water quality $(\mathrm{pH}$, temperature, dissolved oxygen and water discharge). Daily average weight observations are carried out once a week. By providing different feeds, FCR is higher and pellet feed is superior to maggot and pellet combination feed. Pellet feeds produce FCR 2.8 and maggot and pellet combination feeds produce 3.79. With the loss of using maggot mixed feed IDR 15.709.111. Based on these results maggot feed experiments given did not provide a better effect than giving full pellet feed.
\end{abstract}

Keywords: Experiment, red tilapia, different feeding, maggot, FCR, Financial Analysis. 


\section{PENDAHULUAN}

Ikan Nila Merah (Oreochromis niloticus) merupakan jenis ikan yang diintrodusikan dari luar negeri. Bibit ikan didatangkan ke Indonesia secara resmi oleh Balai Penelitian Perikanan air Tawar Bogor dari Lukang Research Station Taiwan pada tahun 1969. Setelah melalui masa penelitian dan adaptasi, barulah ikan ini disebarluaskankepada petani ikan diseluruh Indonesia (Djarijah, 1995). Nila Merah juga merupakan jenis ikan yang mempunyai nilai ekonomis tinggi dan merupakan komoditas andalan di perairan air tawar Indonesia yang sangat digemari oleh masyarakat baik lokal maupun mancanegara. Berdasarkan sumber data dari Kementerian kelautan dan Perikanan (KKP) produksi ikan nila setiap tahunnya berkisar 2-3 juta ton (KKP, 2018).

Hal ini menunjukan bahwa budidaya ikan nila memiliki potensi cukup besar untuk dikembangkan. Ikan ini juga memiliki beberapa sifat yang menguntungkan antara lain cara budidaya yang mudah, harga relatif terjangkau, dan memiliki kemampuan beradaptasi yang baik terhadap lingkungan (Monalisa \& Minggawati, 2010). Selain itu, Ikan Nila Merah juga merupakan salah satu spesies yang dapat dibudidayakan di kolam air deras karena kemampuannya yang dapat beradaptasi pada segala jenis kolam (Ratnawati, 2010). Kolam air deras merupakan wadah budidaya ikan yang airnya mengalir secara terus menerus dalam jumlah tertentu, denggan bentuk dan ukuran bervariasi seperti segi empat atau oval.

Pembudidayaan ikan dengan kolam air deras pada prinsipnya memanfaatkan aliran air yang relatif deras untuk meningkatkan daya dukung kolam guna menunjang pertumbuhan ikan (Ratnawati, 2010). Ikan Nila Merah yang dibudidayakan di kolam air deras memiliki lebih banyak keunggulan dibandingkan dengan yang dibudidayakan di tempat lain seperti waduk karena ukurannya lebih besar. Aliran air yang relatif deras akan membuat kandungan oksigen yang terkandung di dalam kolam lebih banyak sehingga pertumbuhan ikan akan maksimal, daging lebih kenyal dan tidak berbau lumpur.

Permasalahan utama dalam budidaya ikan Nila Merah dihadapkan pada kendala tingginya biaya pakan dan waktu budidaya yang lama. Biaya pakan dalam produksi berkisar 60 - 70\% dari keseluruhan biaya (Yanuar, 2017). Oleh karena itu, dibutuhkan inovasi pada pakan untuk menekan biaya produksi. Pakan alternatif diharapkan dapat 
menjawab permasalahan pakan yang ada saat ini yaitu harga pakan ikan yang terus naik, masalah pencemaran lingkungan perairan karena penumpukan sisa pakan dan munculnya berbagai macam penyakit yang menyebabkan kematian pada ikan. Menteri Kelautan dan Perikanan Edhy Prabowo (14/01/2020), Jakarta, melalui kabar iNews.id menyatakan inovasi penggunaan pakan alternatif untuk budidaya ikan menggunakan Maggot atau yang dikenal dengan Black Soldier Fly (BSF) harus kita dukung.

Maggot adalah serangga pemakan bahan organik, sehingga protein serangga ini berkualitas tinggi dan menjadi sumber protein yang baik bagi ikan. Protein pada maggot berkisar $43,22 \%$ (Newton et al, 2005). Untuk mengefisiensinya perlunya adanya penggantian pakan berupa maggot yang dapat mengatasi masalah tersebut. Pakan Maggot dapat dijadikan alternatif sebagai subsitusi pakan komersial (pakan tepung ikan) dengan diterapkan pada pembesaran ikan nila air deras dan di analisa terkait performa budidaya dan profit yang yang akan diperoleh.

Penggunaan maggot sebagai pakan ikan, bisa diberikan dalam dua cara. Yaitu secara langsung (maggot hidup) dan tidak langsung dengan cara memproses menjadi tepung maggot. Tepung maggot digunakan sebagai sumber protein pakan menggantikan tepung ikan. Penggunaan pakan maggot telah dilakukan pada ikan nila Balai Benih Ikan (BBI) Bontomanai Kabupaten Gowa.

Hasilnya cukup sangat memuaskan. Substitusi maggot segar dengan pakan komersial pada ikan Nila menunjukan bahwa yang diberikan pakan substitusi maggot hidup 50\% dan pakan komersial $50 \%$ menghasilkan hasil sintasan $100 \%$, FCR 1,6 dari 1,9 dan efisiensi pakan yang baik (Murni, 2013). Tujuan penelitian ini adalah untuk membandingkan pengaruh kombinasi maggot dengan pellet (Hermetia illusence) dan pakan buatan pada produksi pembesaran ikan Nila Merah (Oreochromis niloticus) sistem kolam air deras.

\section{MATERI DAN METODE}

\section{Tempat dan Waktu Penelitian}

Penelitian dilaksanakan dari bulan Maret 2020 sampai dengan bulan Mei 2020. Tempat penelitian di PT Ikan Bangun Indonesia (IWAKE), Cinangneng, Bogor, Jawa barat.

\section{Alat dan Bahan}

Wadah yang digunakan dalam penelitian ini adalah Kolam Air Deras 
(KAD) dengan bentuk persegi delapan dengan ukuran 23,83 $\mathrm{m}^{2}$ sebanyak 3 buah dan memiliki kecepatan arus 1,8 meter/detik, alat pengukuran parameter kualitas air meliputi: thermometer, $\mathrm{pH}$ meter, DO Testkit, Stopwatch dan timbangan digital. Benih ikan yang digunakan adalah ikan dengan bobot \pm 26 g/ekor. Padat tebar 21 ekor $/ \mathrm{m}^{3}$. Jenis pakan uji yang digunakan dalam penelitian ini yaitu pakan buatan (pellet) dengan kadar protein $25-27 \%$ dan larva maggot umur 14 hari.

\section{Prosedur Penelitian}

Pelaksanaan penelitian meliputi kegiatan antara lain: Pra produksi, Produksi dan Pasca Panen yang terdiri dari pengamatan pertumbuhan mutlak, laju rata rata pertumbuhan harian, kelansungan hidup, rasio konversi pakan, pengukuran kualitas air, serta perbandingan efisiensi dan analisa finansial.

Ikan uji dipelihara 30 hari dan diberikan berupa pakan buatan (pellet) dengan kadar protein $25-27 \%$ ukuran 3 mm dan larva umur 14 hari. Frekuensi pemberian pakan diberikan 3 kali sehari yaitu pada pukul 08.00, 12.00 dan 16.00 dengan dosis $5 \%$ dari biomassa dengan rancangan sebagai berikut: a. KAD 13: pakan pellet $100 \%$

b. KAD 14: maggot 50\% dan pellet 50\%.

c. KAD 15: maggot 50\% dan pellet 50\%. Selain itu, dilakukan pengukuran parameter kualitas air yaitu suhu, $\mathrm{pH}$, oksigen terlarut dan debit air. Pengukuran suhu dilakukan dengan thermometer, $\mathrm{pH}$ dengan $\mathrm{pH}$ meter, oksigen terlarut dengan DO Testkit dan Stopwatch.

\section{Pertumbuhan Mutlak}

Pertamabahan bobot ikan diukur dengan menggunakan timbangan elektrik dengan ketelitian 0,01 gram dan dilakukan setiap minggu sampai akhir penelitian. Untuk menghitung laju pertumbuhan rumus yang dikemukakan oleh (Ashuri, 2016) yaitu:

$$
\begin{aligned}
& \mathbf{W}=\boldsymbol{W} \boldsymbol{t}-\boldsymbol{W o} \\
& \mathrm{W}=\text { Pertumbuhan bobot }(\mathrm{g}) \\
& \mathrm{Wt}=\text { Bobot ikan akhir }(\mathrm{g}) \\
& \text { Wo }=\text { Bobot ikan awal }(\mathrm{g})
\end{aligned}
$$

\section{Rata-rata Pertumbuhan Harian}

Untuk menghitung rata rata pertumbuhan harian ikan rumus yang dikemukakan oleh Ashuri (2016) yaitu:

$$
\mathrm{ADG}=\frac{(\text { Retara } W t-\text { Retara } W o)}{\text { Waktu }}
$$

\section{Kelangsungan hidup (SR)}


Untuk menghitung tingkat kelangsungan hidup ikan rumus yang dikemukakan oleh Ashuri (2016) yaitu:

$$
\mathrm{SR}=\frac{(N t)}{N o} \times 100 \%
$$

\section{Dimana :}

$\mathrm{SR}=$ Survival Rate $(\%)$

$\mathrm{Nt}=$ Jumlah ikan akhir pemeliharaan

No $=$ Jumlah ikan awal pemeliharaan

\section{Rasio Konversi pakan (FCR)}

Untuk menghitung rasio konversi pakan rumus yang dikemukakan oleh Ashuri (2016) yaitu:

$$
\text { FCR }=\frac{\text { (Jumlah Akumulasi Pakan) }}{\text { Total Biomass }}
$$

\section{Analisa Usaha}

Pada suatu usaha pembesaran harus dianalisis terkait analisa finansialnya. analisa finansial juga berperan untuk menentukan tindakan untuk memperbaiki dan meningkatkan keuntungan usaha. Analisa usaha juga memperkirakan resiko yang timbul saat proses budidaya (Carman $\&$ Sucipto, 2019).

\section{Biaya Tetap (Fixed Cost)}

Biaya tetap adalah jumlah biayabiaya yang tetap dibayar perusahaan (produsen) berapapun tingkat outputnya. jumlah biaya tetap adalah tetap dan tidak mengalami penyusutan seperti sewa gedung dan lain-lain (Primyastanto, 2011).

\section{Biaya Variabel (Variable Cost)}

Biaya variabel total adalah jumlah biaya-biaya yang berubah menurut tinggi rendahnya output yang diproduksikan. Misalnya biaya untuk bahan mentah, upah, biaya angkut dan lain-lain (Primyastanto, 2011).

\section{Biaya Total (Total Cost)}

$$
\text { Biaya Total merupakan }
$$
pengeluaran total usaha yang didefinisikan sebagai semua nilai masukkan yang habis terpakai atau dikeluarkan didalam produksi, tetapi tidak termasuk tenaga kerja keluarga.

\section{Revenue Cost Ratio (RC Ratio)}

Revenue Cost Ratio bertujuan untuk melihat keuntungan relatif suatu usaha dalam satu tahun terhadap biaya yang dipakai dalam kegiatan tersebut. Suatu usaha dikatakan layak bila R/C lebih besar dari satu. Hal ini menggambarkan semakin tinggi nilai $\mathrm{R} / \mathrm{C}$, maka tingkat keuntungan suatu usaha akan semakin tinggi (Primyastanto, 2011). Dalam menentukan nilai $\mathrm{RC}$ ratio dilakukan dengan rumus menurut Primyastanto (2011): 


\section{BEP (Break Event Point)}

$$
\mathrm{R} / \mathrm{C} \text { Ratio }=\frac{\text { Pendapatan Total }(\mathrm{Rp})}{\text { Biaya Total }}
$$

Break Even Point atau titik impas merupakan keadaan dimana suatu usaha berada pada posisi tidak memperoleh keuntungan dan tidak megalami kerugian. BEP merupakan teknik analisa yang mempelajari hubungan antara biaya tetap, biaya variabel, volume kegiatan dan keuntungan. Dengan rumus menurut Primyastanto (2011), sebagai berikut:

BEP Unit $=\frac{\text { Biaya Tetap }}{\text { Harga Per Unit - Biaya variabel Unit }}$

BEP Harga $=\frac{\text { Biaya Tetap }}{1-\text { harga Per unit } / \text { Variabel per unit }}$

\section{Payback Period (PP)}

Payback Period merupakan metode yang mencoba mengukur seberapa cepat investasi bisa kembali. Karena itu satuan hasilnya bukan persentase, tetapi satuan waktu. Jika payback period ini lebih pendek dari pada yang disyaratkan, maka proyek dikatakan menguntungkan. Adapun perhitungan yang dilakukan berdasarkan rumus menurut Primyastanto (2011), sebagai berikut:

$\mathrm{PP}=\frac{\text { Investasi }(\mathrm{Rp})}{\text { Kas Bersih Pertahun }} \times 1$ tahun

Keuntungan (Laba/Rugi)
Menurut Primyastanto

(2011) Perhitungan keuntungan (Laba/Rugi) dapat dilakukan dengan rumus sebagai berikut:

Laba $/$ Rugi $=$ Total penjualan - Total Biaya

\section{HASIL DAN PEMBAHASAN}

Pertumbuhan Mutlak

Grafik menunjukan bahwa pertambahan berat ikan yang tertinggi diperoleh pada KAD 13 kemudian KAD 15 dan yang terendah KAD 14 (Gambar 1). Hal ini menunjukan bahwa pemberian kombinasi pellet dan maggot tidak memberikan pengaruh terhadap pertumbuhan ikan.

Respon ikan pada KAD 13 juga menunjukan kecenderungan yang lebih cepat dibandingkan dengan KAD 14 dan 15. Jenis dan kualitas pakan yang berbeda akan mempengaruhi laju pertumbuhan ikan nila (Yanuar, 2017). Selanjnutnya, Khasani (2013), menambahkan bahwa kecukupan pakan, keseimbangan energi, dan kandungan nutrisi, mampu menstimulus ikan untuk merespons keberadaan pakan tersebut, yang dikenal dengan atraktan. Zat atraktan inilah yang membuat pakan pellet cenderung lebih disukai daripada pakan maggot.

Average Daily Growth (ADG) 
Rata rata pertumbuhan harian pada setiap kolam percobaan menunjukan penurunan yaitu pada minggu ke 2 dan 3 (Gambar 2). Hal ini disebabkan oleh intensitas dan curah hujan yang tinggi yang mempengaruhi kualitas sumber air pada KAD sehingga nafsu makan ikan menurun. Pertumbuhan harian rata rata ikan Nila merah pada KAD 13 sebesar $1-2.32$ gram/hari, sedangkan pada KAD 14 dan 15 lebih rendah yaitu 0,62 - 1,82 gram/hari. Pertumbuhan dipengaruhi oleh faktor internal seperti kondisi tubuh ikan tersebut. Sedangkan faktor eksternal seperti faktor lingkungan_seperti curah hujan yang tinggi dan pakan kurang bernutrisi sangat berpengaruh pada pertumbuhan ikan (Ardita, 2015).

\section{Kelangsungan Hidup (SR)}

Kelangsungan hidup ikan nila merah pada setiap KAD sebesar 90\%. Tingkat kelulushidupan tertinggi terdapat pada KAD 13. Kelulushidupan ikan nila sangat ditentukan oleh pakan dan kondisi lingkungan sekitar (Iskandar \& Elrifadah, 2015). Ikan yang tumbuh baik dapat mempengaruhi kehidupannya karena ikan yang mampu mempergunakan makanan dengan optimal akan dapat memanfaatkan hasil metabolisme untuk tumbuh dan bertahan hidup (Setiyowati et al., 2017).

\section{Rasio Konversi Pakan (FCR)}

Nilai FCR yang terendah diperoleh pada KAD 13 yakni sebesar 2,80, diikuti KAD 15 sebesar 3,59 dan KAD 14 sebesar 3,79. Menurut SNI (2015), menyatakan angka konversi pakan ikan Nila kolam air deras sebaiknya 1,2 $-1,5$. Hasil pengamatan belum sesuai standar yang ditetapkan. Kondisi ini terjadi diduga karena ikan belum terbiasa diberi pakan berupa maggot kemudian bau dari pakan antara pellet dan maggot juga menjadi hal yang harus diperhatikan. Selain itu, perbedaan respon ikan juga menjadi salah satu yang terpenting. Pada saat pemberian pakan pellet respon ikan lebih cepat 2 kali lipat dibandingkan dengan pakan maggot.

Tabel 1. Hasil perbandingan efisiensi

\begin{tabular}{lcc}
\hline Keterangan & Pellet & Maggot dan Pellet \\
\hline FCR & 2,80 & 3,79 \\
SR (\%) & 94,2 & 90,4 \\
ADG (gram/hari) & 2,3 & 1,8 \\
Biomassa (Kg) & 30 & 25 \\
\hline Berpedoman pada variasi kebiasaan & memakan dan menyerap, maka sangat \\
seperti rangsang tanggap, pencarian, & realistis bahwa penambahan atraktan pada
\end{tabular}


pakan pellet itulah yang mempengaruhi ikan dan membuat ikan lebih tertarik, sehingga waktu ikan untuk makan lebih pendek (Khasani, 2013). Disamping itu, pakan maggot yang diberikan juga tidak diamati secara detail terkait penyerapan pakan oleh lambung ikan. Selanjutnya, perbedaan respon ikan juga menjadi salah satu yang terpenting. Pada saat pemberian pakan pellet respon ikan lebih cepat 2 kali lipat dibandingkan saat diberikan pakan maggot. Variasi kebiasaan ikan seperti rangsangan pakan, menjadi faktor yang berpengaruh (Khasani, 2013).

\section{Kualitas Air}

Hasil pengukuran kualitas air selama pemeliharaan menunjukan kondisi optimal untuk kegiatan budidaya dan tidak terdapat

Tabel 2. Pengukuran Kualitas Air fruktuasi yang signifikan (Tabel 2).

\section{Perbandingan Efisiensi}

Penggunaan pakan maggot dalam pemeliharaan ikan nila ini adalah untuk melihat sejauh mana efisiensi pakan yang dikombinasikan dengan maggot. Sehingga dengan adanya pemberian pakan maggot ini bisa dijadikan sebagai acuan dari efesiensi penggunaan pakan maggot sebagai pengganti pakan tepung ikan (pellet). Pakan kombinasi maggot dan pellet belum efisien dibandingkan dengan pakan pellet (Tabel 1). Pakan kombinasi maggot dan pellet menghasilkan biomassa yang lebih rendah dibandingkan dengan pakan pellet. Hal ini diduga ikan nila merah belum terbiasa terhadap pakan maggot yang diberikan.

\begin{tabular}{llll}
\hline No & Parameter & Standar & Hasil \\
\hline 1. & $\mathrm{pH}$ & $7-8$ & $7.6-7.9$ \\
2. & Suhu $\left({ }^{\circ} \mathrm{C}\right)$ & $22-32$ & $23-26.5$ \\
3. & Oksigen terlarut $(\mathrm{mg} / \mathrm{L})$ & $5-7$ & 5 \\
4. & Debit $\left(\mathrm{m}^{3} /\right.$ detik $)$ & $0,02-0,9$ & 0,318 \\
\hline
\end{tabular}

\section{Analisa Finansial}

Analisis aspek ekonomi digunakan untuk menjelaskan finansial usaha pembesaran ikan Nila Merah. Selain itu perhitungan analisa finansial juga dapat menjadi tolak ukur kelayakan suatu usaha. Perhitungan analisis finansial menggunakan asumsi berdasarkan yang dialami selama penelitian dan wawancara dengan pemilik perusahaan. Biaya produksi yang dikeluarkan dengan pemberian pakan pellet ialah Rp 42.959.111. Sedangkan biaya produksi yang dikeluarkan pada pemberian pakan 
kombinasi maggot dan pellet ialah $\mathrm{Rp}$ 41.609.111. Selisih biaya produksi antara pakan pemberian pakan pellet dan kombinasi maggot dan pellet ialah $\mathrm{Rp}$ 1.350.000. Hal ini disebabkan harga pakan pellet dan maggot yang berbeda.

Tabel 3. Analisa produksi budidaya ikan nila dengan kombinasi pakan dan tanpa kombinasi

\begin{tabular}{lll}
\hline \multicolumn{1}{c}{ Keterangan } & \multicolumn{1}{c}{ Full pellet } & Kombinasi maggot dan pellet \\
\hline Ukuran panen (gram) & 200 & 200 \\
Jumlah Tebar (ekor) & 500 & 500 \\
SR (\%) & 89 & 85 \\
Jumlah Panen (kg) & 1125 & 925 \\
Harga pakan (Rp) & 8000 & 7500 \\
Biaya produksi keseluruhan (Rp) & 42.959 .111 & 41.609 .111 \\
Pendapatan (Rp) & 31.500 .000 & 25.900 .000 \\
Laba/Rugi (Rp) & -11.459 .111 & -15.709 .111 \\
R/C ratio & 0,73 & 0,62 \\
\hline
\end{tabular}

Harga jual ikan yang didapat dari perhitungan dalam 25 kolam pengamatan selama satu siklus yaitu Rp 28.000/Kg. Pendapatan perlakuan pemberian pakan pellet ialah Rp 31.500.000, Pendapatan perlakuan pemberian pakan kombinasi maggot dan pellet ialah $\mathrm{Rp} 25.900 .000$. Perlakukan pemberian pakan pellet

memperoleh kerugian sebesar $\mathrm{Rp}$ 11.459.111, yang dimungkinkan disebabkan oleh menggunakan pakan yang proteinnya rendah sehingga mempengaruhi pertumbuhan. Pemberian pakan kombinasi maggot dan pellet juga mengalami kerugian lebih besar sebesar Rp 15.709.111, disebabkan karena menghasilkan FCR yang terlalu tinggi ditambah lagi pakan maggot diperoleh/dibeli dari salah satu perusahaan maggot sehingga mempengaruhi biaya produksi ikan nila merah pada sistem KAD. Berdasarkan hasil analisa finansial pemberian pakan kombinasi maggot dan pellet belum efisien untuk diterapkan pada ikan nila merah.

\section{KESIMPULAN}

Penerapan pemberian pakan kombinasi maggot dan pellet pada ikan nila merah dengan sistem kolam air deras belum efisien. Hal ini disebabkan oleh bebrapa faktor seperti feeding habbit dan aklimatisasi jenis pakan yang perlu dilakukan. Selain itu, kombinasi pakan maggot dan pellet tidak memberikan 
keuntungan finansial yang signifikan.

\section{UCAPAN TERIMA KASIH}

Penelitian ini merupakan bagian dari percobaan perusahaan yang didanai oleh PT Ikan Bangun Indonesia. Ucapan terima kasih diberikan kepada PT Ikan Bangun Indonesia dan semua pihak yang telah terlibat dalam penelitian.

\section{DAFTAR PUSTAKA}

Ardita, N. 2015. Pertumbuhan dan rasio konversi pakan ikan nila (Oreochromis niloticus) dengan penambahan probiotik. Bioteknologi, 12: 16-21. https://doi.org/10.13057/biotek/c12 0103.

Ashuri, W. C. 2016. Model segmentasi dan prospek usaha budidaya ikan nila (Oreochromis sp.) di kawasan pertambakan pesisir utara jawa barat.

Carman, O., \& Sucipto, A. 2019. budidaya ikan nila panen 75 hari. Jakarta: penebar swadaya.

Djarijah, A. S., 1995. Nila Merah Pembenihan don Pembesaran secara Intensif. Penerbit Kanisius. Yogyakarta.Iskandar, R., \& Elrifadah, E. 2015. Pertumbuhan dan Efisiensi Pakan Ikan Nila (Oreochromis Niloticus) yang Diberi Pakan Buatan Berbasis Kiambang. Ziraa'ah Majalah Ilmiah Pertanian, 40(1), 18-24.

Khasani, I. 2013. Atraktan pada Pakan Ikan: Jenis, Fungsi, dan Respons
Ikan. Media akuakultur, 8(2): 127134.

KKP, k. k. p. 2018. Refleksi \& outlook 2018. In K. K. d. Perikanan (Ed.).

Monalisa, S. S., \& Minggawati, I. 2010. Kualitas Air yang Mempengaruhi Pertumbuhan Ikan Nila ( Oreochromis sp.) di Kolam Beton dan Terpal. 5, 526-530.

Murni, M. 2013. Optimasi Pemberian Kombinasi Maggot dengan Pakan Buatan terhadap Pertumbuhan dan Sintasan Ikan Nila (Oreochromis Niloticus). Octopus: Jurnal Ilmu Perikanan, 2(2): 192-198.

Primyastanto, M. 2011. Feasibility Study Usaha Perikanan. Malang: UB Press.

Ratnawati, R. A. D. 2010. Analisis Usaha

Pembesaran Ikan Nila Merah (Oreochromis Sp) Di Kolam Air Deras. 1-28.

Setiyowati, D., Zainuddin, M., Wati, T. S., \& Qomaruddin, M. 2017. Respon Pemanfaatan Pakan Terhadap Pertumbuhan Ikan Nila Merah (Oreochromis Niloticus) Pada Bak Berbahan Limbah B3 Fly Ash Dari Pltu Tanjung Jati B Jepara. Jurnal Enggano, 2(2): 185-195.

SNI. 2015a. Cara budidaya ikan yang baik (CBIB) In Bagian 4 : Ikan air tawar (Vol. SNI 8228.4:2015). Jakarta: Badan Standarisasi Nasional.

SNI. 2015b. Pembesaran ikan nila (Oreochromis niloticus, Linnaeus 1758) di kolam air deras. In (Vol. SNI 8124:2015). Jakarta: Badan Standarisasi Nasional. 
Journal of Aquaculture Science

DOI: https://doi.org/10.31093/joas.v5i2.97
Oktober 2020 vol 5 (2): 88-98

Online pada http://joas.co.id
Yanuar, V. 2017. Pengaruh Pemberian Jenis Pakan Yang Berbeda Terhadap Laju Pertumbuhan Benih
Ikan Nila (Oreochiomis niloticus) dan Kualitas Air Di Akuarium Pemeliharaan. 42, 91-99. 